\title{
POTENSI GELATIN IKAN BANDENG (CHANOS CHANOS) SEBAGAI BIOINHIBITOR LOGAM BESI PADA LARUTAN NACL 3\% DAN HCL 3\%
}

\section{POTENTIALS OF MILKFISH (Chanos chanos) GELATIN AS BIOINHIBITOR OF IRON METALS ON 3\% NaCI SOLUTION AND 3\% HCI}

\author{
Tri Paus Hasiholan Hutapea \\ Jurusan Teknologi Hasil Perikanan, Fakultas Perikanan dan Ilmu Kelautan, \\ Universitas Borneo Tarakan \\ Jl. Amal Lama No. 01, Tarakan, Kalimantan Utara \\ Email: hutapea2606@gmail.com
}

\begin{abstract}
ABSTRAK
Logam besi merupakan logam yang paling banyak ditemukan dan sering dimanfaatkan untuk berbagai kebutuhan. Logam besi memiliki kekurangan yaitu mudah mengalami korosi atau kerusakan. Salah satu cara untuk menghambat proses korosi pada logam besi yaitu dengan penambahan inhibitor. Perkembangan penelitian mengenai inhibitor korosi adalah penggunaan bahan alam sebagai bioinhibitor korosi. Pada penelitian ini digunakan gelatin ikan bandeng (Chanos chanos) sebagai bioinhibitor korosi logam besi. Penelitian ini terbagi menjadi dua tahap. Tahap pertama adalah ekstraksi gelatin ikan bandeng (Chanos chanos) dan tahap kedua adalah pengujian fungsi gelatin sebagai bioinhibitor korosi logam besi pada media larutan $\mathrm{NaCl} 3 \%$ dan $\mathrm{HCl} 3 \%$. Hasil yang didapat potensi gelatin sebagai bioinhibitor logam besi lebih besar pada larutan $\mathrm{NaCl}$ $3 \%$. Hal ini ditunjukkan dengan nilai efisiensi bioinhibitor yang cukup besar yaitu $68,23 \%$, sedangkan efesiensi bioinhibitor pada larutan $\mathrm{HCl} 3 \%$ yaitu $38,68 \%$.
\end{abstract}

\section{Kata Kunci : Chanos chanos; Gelatin; Inhibitor; Korosi; Logam Besi}

\begin{abstract}
Ferrous is the most common metal that was found and used for various needs. It has a disadvantage that is susceptible to get corrosion or damage. One of the best options to inhibit the corrosion process by adding inhibitors. The development of research focuses on using natural materials as corrosion bio inhibitors. In this study, milkfish gelatin (Chanos chanos) was implemented as a bio inhibitor of ferrous metal corrosion. This research was divided into two stages. The first step was the extraction of milkfish gelatin (Chanos chanos) and the second was testing the function of gelatin as bio inhibitor for ferrous metals in $3 \% \mathrm{NaCl}$ and $3 \% \mathrm{HCl}$ solution media. The results obtained that the potential of gelatin as a bio inhibitor was greater in $3 \% \mathrm{NaCl}$. It was showed by the higher value of bio inhibitor efficiency as $68.23 \%$, while in $3 \% \mathrm{HCl}$ solution was $38.68 \%$.
\end{abstract}

\section{Keywords: Chanos chanos; Corrosion; Ferrous Metals; Gelatin; Inhibitors}

\section{PENDAHULUAN}

Logam berat ialah unsur logam dengan berat molekul yang tinggi. Dalam udara terbuka logam mudah teroksidasi sehingga akan menimbulkan bercak cokelat. Semakin lama, bercak cokelat ini akan semakin banyak sampai menutupi seluruh permukaan besi. Bercak coklat 
tersebut adalah karat atau korosi (Das, 2012).

Korosi merupakan proses oksidasi suatu logam dengan udara dan elektrolit yang akan mengalami reduksi, proses korosi merupakan proses elektrokimia. Dampak yang akan dialami dengan adanya korosi meliputi dampak finansial dan safety, seperti; penurunan kekuatan material, penipisan, kebocoran fluida, penurunan sifat permukaan material, penurunan nilai / hasil produksi, modification (Sidiq, 2013). Kecepatan korosi pada suatu bahan dipengaruhi oleh kelembaban udara dan kadar garam atau asam (Caniago, 2006). Korosi yang terjadi pada logam tidak dapat dihindari, tetapi hanya dapat dicegah dan dikendalikan sehingga struktur atau komponen mempunyai masa pakai yang lebih lama.

Salah satu cara yang dapat dilakukan untuk mencegah terjadinya korosi adalah dengan penggunaan inhibitor korosi. Inhibitor korosi adalah sautu zat kimia yang dapat menurunkan laju penyerangan korosi lingkungan terhadap suatu logam jika ditambahkan kedalam suatu lingkungan (Sidiq, 2013). Penggunaan bahan alami seperti ekstrak daun, biji, buah, dan akar, yang memiliki senyawa organik dapat mengurangi laju korosi dan biasa disebut sebagai bio inhibitor korosi (Mulyaningsih and Mujiarto, n.d.).

Penelitian mengenai bio inhibitor korosi telah banyak dilakukan. Penggunaan bahan alam sebagai material bio inhibitor korosi mampu secara maksimal dalam menghambat laju korosi pada logam. (Affifah et al., n.d.; Ali et al., 2014; Hidayatulloh et al., 2017; Mulyaningsih and Mujiarto, n.d.; Rahmi et al., 2018). Salah bahan alam adalah gelatin. Gelatin merupakan senyawa turunan protein yang berasal dari hewan. Gelatin telah banyak dimanfaatkan diberbagai bidang. Gelatin dimanfaatkan dalam mengolah air (Sugihartono, 2016) dan sebagai material biosensor (Hutapea et al., n.d.). Pada penelitian ini, gelatin akan dimanfaatkan sebagai sebagai bioinhibitor korosi besi dalam larutan $\mathrm{NaCl} 3 \%$ dan $\mathrm{HCl} 3 \%$. Gelatin yang digunakan diekstrak dari ikan bandeng (Chanos chanos).

\section{METODE PENELITIAN \\ Ekstraksi Gelatin}

Ekstraksi dilakukan dengan beberapa tahap. Tahap pertama dilakukan perendaman tulang ikan bandeng yang telah bersih kedalam $0,1 \mathrm{M} \mathrm{NaOH}$ selama 48 jam. Setelah itu dicuci hingga $\mathrm{pH}$ netral dan dilanjutkan perendaman dengan $\mathrm{HCl} 0,1 \mathrm{M}$ selama 72 jam. Selanjutnya dicuci hingga $\mathrm{pH}$ netral dan dilakukan proses ekstraksi menggunakan pelarut air dengan perbandingan tulang ikan bandeng dan air adalah 1:3. Proses ekstraksi dilakukan pada suhu $55{ }^{\circ} \mathrm{C}$ selama 4 jam (Hutapea et al., 2020)

\section{Pengujian Gelatin Sebagai Bioinhibitor}

Plat besi (Gambar 1) terlebih dahulu ditimbang. Kemudian dilakukan perendaman pada larutan $\mathrm{NaCl} 3 \%$ dan $\mathrm{HCl} 3 \%$ selama 18 jam. Setelah itu plat dibersihkan dan ditimbang kembali untuk mengetahui berat akhir. Uji gelatin sebagai bioinhibitor, dilakukan dengan cara penambahan gelatin pada larutan $\mathrm{NaCl} 3 \%$ dan $\mathrm{HCl} 3 \%$ dengan massa gelatin yaitu 0.025 gram.

\section{Analisis Data}

Dalam penetuan laju korosi, digunakan rumus berikut ini :

$$
C R(m p y)=\frac{W \cdot K}{D \cdot A \cdot T}
$$

Dimana $\mathrm{K}$ merupakan konstanta dengan nilai 534. Untuk menentukan efesiensi inhibitor maka digunakan rumus :

Efesiensi $=\frac{C R a-C}{C R a} \times 100 \%$

Dimana CRa merupakan laju korosi tanpa inhibitor dan CRb adalah laju korosi dengan inhibitor. 


\section{HASIL DAN PEMBAHASAN}

Salah satu cara menghambat laju korosi dari logam besi adalah dengan menambahkan inhibitor. Penggunaan bahan alam sebagai inhibitor disebut sebagai bioinhibitor. Bahan alam secara efektif dapat menurunkan laju korosi pada logam (Erna et al., 2012). Penentuan laju korosi didasarkan pada pengurangan massa logam besi akibat proses korosi oleh larutan $\mathrm{NaCl} 3 \%$ dan $\mathrm{HCl} 3 \%$. Penelitian ini menunjukkan adanya pengaruh penambahan bahan alam yaitu gelatin ikan bandeng (Chanos chanos) terhadap laju korosi pada logam besi. Pengujian dilakukan pada media larutan yang berbeda yaitu larutan $\mathrm{NaCl} 3 \%$ dan $\mathrm{HCl} 3 \%$. Tujuan menggunakan dua larutan yang berbeda adalah untuk mengetahui efesiensi gelatin sebagai bioinhibitor. Berdasarkan hasil penelitian (Tabel 1), menunjukkan terjadi penurunan laju korosi terhadap logam besi pada larutan $\mathrm{NaCl} 3 \%$ dan $\mathrm{HCl} 3 \%$ dengan penambahan gelatin ikan bandeng. Fungsi bioinhibitor adalah menghambat laju korosi dengan cara melakukan gangguan reaksi oksidasi reduksi logam besi dengan larutan $\mathrm{NaCl}$ dan $\mathrm{HCl}$. Diduga gelatin akan melapisi permukaan logam besi. Hal ini akan menyebabkan kesempatan logam besi bereaksi dengan $\mathrm{NaCl}$ dan $\mathrm{HCl}$ akan semakin berkurang. Bahan alam sebagai bioinhibitor korosi logam akan melapisi permukaan logam agar menghambat terjadinya proses korosi logam (Wahyuni and $A b, 2014)$.

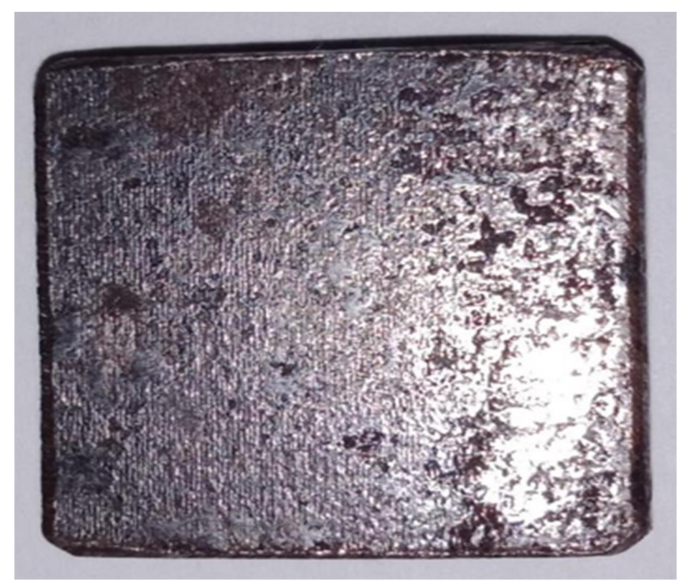

Gambar 1. Plat Logam Besi

Tabel 1. Hasil Pengujian Bioinhibitor

\begin{tabular}{llll}
\hline Larutan & Perlakuan & Laju Korosi (mpy) & Efesiensi Inhibitor (\%) \\
\hline \multirow{2}{*}{$\mathrm{NaCl} 3 \%$} & Tanpa Bioinbitor & 0,00130435 & \multirow{2}{*}{68,23} \\
\cline { 2 - 3 } & Dengan Bioinhibitor & 0,00041431 & \\
\hline \multirow{2}{*}{$\mathrm{HCl} 3 \%$} & Tanpa Bioinbitor & 0,05802698 & \multirow{2}{*}{38,68} \\
\cline { 2 - 4 } & Dengan Bioinhibitor & 0,03558101 & \\
\hline
\end{tabular}

Nilai efesiensi inhibitor kemudian dihitung dengan membandingkan laju korosi logam besi tanpa dan dengan penambahan inhibitor. Nilai efesiensi menunjukkan efektifitas bioinhibitor dalam menghambat laju korosi dari logam
(Fahrurrozie et al., 2010). Hasil perhitungan menunjukkan nilai efesiensi gelatin sebagai bioinhibitor korosi logam besi pada larutan $\mathrm{NaCl}$ sebesar 68,23\%, sedangkan pada larutan $\mathrm{HCl} 3 \%$ sebesar $38,68 \%$. Berdasarkan nilai yang 
didapatkan, gelatin sebagai inhibitor korosi logam besi lebih efektif bekerja pada larutan $\mathrm{NaCl} 3 \%$ daripada larutan $\mathrm{HCl} 3 \%$. Hal ini diduga asam klorida merusak gugus aktif dari gelatin dalam menghambat korosi, sehingga gelatin menjadi kurang efektif dalam menghambat laju korosi logam besi pada larutan $\mathrm{HCl} 3 \%$. Gelatin ikan bandeng sebagai bioinhibitor korosi logam besi akan bekerja secara efektif pada larutan garam.

\section{KESIMPULAN}

Berdasarkan hasil penelitian dapat disimpulkan bahwa gelatin ikan bandeng dapat dimanfaatkan sebagai bioinhibitor korosi logam besi. Laju korosi logam besi pada larutan $\mathrm{NaCl} 3 \%$ dan $\mathrm{HCl} 3 \%$ mengalami penurunan dengan penambahan gelatin ikan bandeng. Efesiensi inhibitor lebih tinggi pada larutan $\mathrm{NaCl} 3 \%$ yaitu sebesar 68,23\%, sedangkan pada larutan $\mathrm{HCl}$ sebesar $38,68 \%$. Hal ini menunjukkan gelatin lebih efektif bekerja sebagai bioinhibitor korosi logam besi pada larutan $\mathrm{NaCl} 3 \%$.

\section{UCAPAN TERIMA KASIH}

Penulis mengucapakan terimakasih kepada Kepala Laboratorium Kualitas Air Fakultas Perikanan dan Ilmu Kelautan Universitas Borneo Tarakan yang telah memfasilitasi dalam pelaksanaan penelitian ini.

\section{DAFTAR PUSTAKA}

Affifah, I., Warganegara, F.M., Bundjali, B., n.d. Uji Kualitatif Dan Kuantitatif Ekstrak Sargassum sp. Dan Gracilaria sp. Sebagai Inhibitor BioKorosi Pada Baja Karbon 14.

Ali, F., Saputri, D., Nugroho, R.F., 2014. Pengaruh Waktu Perendaman Dan 20, 10.

Caniago, Z.B., 2006. Kecepatan Korosi Oleh 3 Bahan Oksidan Pada Plat Besi $2,6$.

Das, A.M., 2012. Studi Dampak Korosi Terhadap Material Baja 5.
Erna, M., Emriadi, E., Alif, A., Arief, S., 2012. Efektifitas Kitosan sebagai Inhibitor Korosi pada Baja Lunak dalam Air Gambut. J. Nat. Indones. 13, 118. https://doi.org/10.31258/jnat.13.2. 118-122.

Fahrurrozie, A., Sunarya, Y., Mudzakir, A., 2010. Efisiensi Inhibis Cairan Ionik Turunan Imidazolin Sebagai Inhibitor Korosi Baja Karbon Dalam Larutan Elektrolit Jenuh Karbon Dioksida 1, 13.

Hidayatulloh, A.B.S., Hendaryati, H., Aisyah, I.S., 2017. Analisa Pengaruh Ekstrak Kulit Buah Naga Sebagai Green Inhibitor Corrosion Pada Laju Korosi Baja ST-42 9.

Hutapea, T.P.H., Madurani, K.A., Kurniawan, F., n.d. Milkfish (Chanos Chanos) Gelatin as Biosensor Material for Chromium Detection. Int. J. Eng. 5.

Hutapea, T.P.H., Rukisah, Muliyadi, Madurani, K.A., Suprapto, Kurniawan, F., 2020. Chemistry and Physic Characterization of Milkfish ( Chanos chanos ) Gelatin from Tarakan, North Borneo, Indonesia. E3S Web Conf. 153, 01012. https://doi.org/10.1051/e3sconf/202 015301012.

Mulyaningsih, N., Mujiarto, S., n.d. Pemanfaatan Teh Sebagai Bioinhibitor Korosi Pegas Daun 7.

Rahmi, H., Ramadhan, R., Radjab, N.S., 2018. Pengaruh Konsentrasi Natrium Alginat Terhadap Gel Ekstrak Daun Teh Hijau (Camellia Sinensis L.) Sebagai Inhibitor Tirosinase. Pharm. J. Farm. Indones. Pharm. J. Indones. 14 , 162. https://doi.org/10.30595/pharmacy. v14i2.1904.

Sidiq, M.F., 2013. Analisa Korosi Dan Pengendaliannya 3, 6 .

Sugihartono, S., 2016. Pemisahan krom pada limbah cair industri penyamakan kulit menggunakan gelatin dan flokulan anorganik. Maj. Kulit Karet Dan Plast. 32, 21. https://doi.org/10.20543/mkkp.v32i 1.900.

Wahyuni, T., Ab, S., 2014. Pemanfaatan Tanin Ekstrak Daun Jambu Biji Terhadap 3, 8. 
